DR. PIERRE MARIE NIGAY (Orcid ID : 0000-0003-2204-6205)

DR. CLARE EMILY WHITE (Orcid ID : 0000-0002-4800-7960)

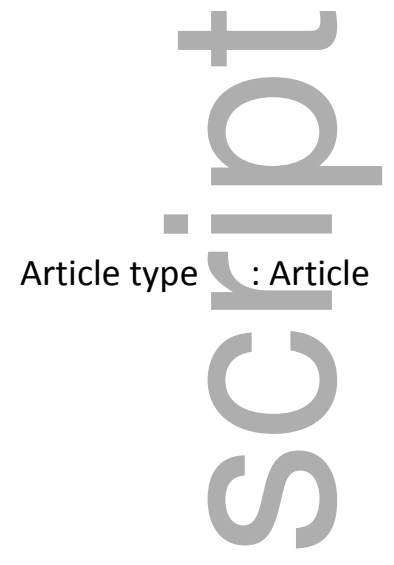

\title{
Structure and Properties of Clay Ceramics for Thermal Energy Storage
}

P.M. NIGAY ${ }^{1,5, *}$, A. NZIHOU ${ }^{1}$, C.E. WHITE ${ }^{2,3}$ and W.O. SOBOYEJO ${ }^{4,5}$

${ }^{1}$ Centre RAPSODEE, Ecole des Mines d'Albi, Albi, France.

${ }^{2}$ Department of Civil and Environmental Engineering, Princeton University, Princeton, New Jersey.

${ }^{3}$ Andlinger Center for Energy and the Environment, Princeton University, Princeton, New Jersey.

${ }^{4}$ Department of Mechanical and Aerospace Engineering, Princeton University, Princeton, New Jersey.

${ }^{5}$ Department of Mechanical Engineering, Worcester Polytechnic Institute, Worcester, Massachusetts.

* Corresponding author: pmnigay@ mines-albi.fr, +33 (0) 563493228.

\begin{abstract}
In this paper, the structure-property relationships of a clay ceramic with organic additives (biomass and biochar) are investigated to develop an alternative material for thermal energy storage. The firing transformations were elucidated using X-ray pair distribution function analysis, differential scanning calorimetry and scanning electron microscopy. It was found that the biomass transformed into porosity, which resulted in a decrease of the specific heat capacity. On the other hand, the biochar remained in the clay ceramic without any interaction This is the author manuscript accepted for publication and has undergone full peer review but has not been through the copyediting, typesetting, pagination and proofreading process, which may lead to differences between this version and the Version of Record. Please cite this article as doi: $10.1111 /$ jace.15014
\end{abstract}

This article is protected by copyright. All rights reserved 
with the clay matrix up to $950^{\circ} \mathrm{C}$. The specific heat capacity of the clay ceramic increased from $1.20 \mathrm{~kJ} / \mathrm{kg} . \mathrm{K}$ to $1.49 \mathrm{~kJ} / \mathrm{kg} . \mathrm{K}$ for a $30 \mathrm{wt} . \%$ addition of biochar. The clay ceramic with a $30 \mathrm{wt} . \%$ addition of biochar also conserved a high flexural strength of $11.1 \mathrm{MPa}$ compared to that of the clay ceramic without organic additives (i.e., 18.9 MPa). Furthermore, the flexural strength only decreased by $23 \%$ after 100 thermal cycles. The crack growth associated with the thermal fatigue was limited by crack bridging and crack trapping. The current results suggest that clay/biochar ceramics can be as efficient as molten salts in thermal energy storage with the added benefit of an ease of use in the physical form of bricks.

Keywords: phase transformations; thermal properties; R-curve; fatigue, energy conversion.

\section{Introduction}

The production of electricity from renewable energy sources is expected to grow in the years ahead. The conversion of solar, wind or biomass power is a sustainable way of reducing our modern dependency on fossil fuels. However, the use of renewables is still limited by the intermittency of the renewable energy sources ${ }^{1}$. For instance, solar powered systems generate electricity during the daytime, while electricity is needed over 24 hours in a day.

Energy storage technologies have emerged to level the intermittent production of electricity from renewable energy sources. These technologies include electrochemical ${ }^{2}$, mechanical ${ }^{3}$ or thermal energy storage ${ }^{4}$. Thermal energy storage is based on a reversible transfer of heat, in the sensible or latent form ${ }^{5}$, that does not require any production of electricity. This makes thermal energy storage a low cost technology which is appropriate for many systems in the production of thermal energy ${ }^{6}$.

For sensible heat storage, materials are introduced in a container and heated. The amount of energy stored is proportional to the mass (i.e., porosity), the specific heat capacity, and the temperature increase of the storage materials. The temperature increase (charging) is usually performed by the circulation of warm air through the storage materials. Subsequently, energy can be reused (discharging) to warm a circulating flow of cool air. The charging/discharging rates are controlled by the shape of the storage materials in the case of a solid medium. In fact, a reduction of the thickness results in a greater exchange at the surfaces of the materials ${ }^{7}$.

Molten salts are widely used in thermal energy storage systems for their high specific heat capacities between $1.10 \mathrm{~kJ} / \mathrm{kg} . \mathrm{K}$ and $1.50 \mathrm{~kJ} / \mathrm{kg} . \mathrm{K}$ in liquid form ${ }^{8}$. However, the utilization of liquid forms requires infrastructure with a complex system of tanks. Concrete is an attractive 
material for thermal energy storage. It has a low cost and relevant specific heat capacities of $0.95 \mathrm{~kJ} / \mathrm{kg} . \mathrm{K}^{9}$. Nevertheless, the thermal degradation of concrete at temperatures greater than $500^{\circ} \mathrm{C}$ limits the utilization of concrete to low-temperature storage solutions ${ }^{10}$.

In contrast, many ceramic materials are stable up to temperatures of $1000^{\circ} \mathrm{C}^{11}$. The ceramic materials are also processed in the form of bricks that makes them convenient for thermal energy storage. However, most of the ceramic materials have low specific heat capacities in comparison with concrete or molten salts $(0.87 \mathrm{~kJ} / \mathrm{kg} . \mathrm{K})^{12}$. The ceramic materials also remain expensive to produce compared to the other materials. Hence, the objective of this study is to investigate the structure-property relationship of a clay ceramic with organic additives (biomass and biochar) to develop an alternative material with a high specific heat capacity.

\section{Materials and Experimental Methods}

\subsection{Raw Materials}

The clay that was used in this study was extracted in the form of lumps from a clay quarry in the Toulouse area (France). The lumps of clay were ground into smaller lumps of around 3 mm using a rolling mill (LA 1527, Vicentini, Vicenza, Italy). The elemental composition of the clay, measured via X-ray fluorescence analysis (Epsilon 3-XL, PanAlytical, Almelo, Netherlands), is given in Table 1 . Note the predominance of silicon and aluminum oxides, with smaller amounts of calcium, iron, potassium and magnesium oxides.

The organic additives that were used in this study consisted of biomass and biochar. The biomass was produced by grinding a hard wood with a knife mill (Pulverisette 15, Fritsch, Idar-Oberstein, Germany), while the biochar was produced by pyrolysis of the biomass at $500^{\circ} \mathrm{C}$. The elemental composition was measured using organic elemental analysis (Flash 2000, Thermo Fisher Scientific, Waltham, MA, USA). The results of the organic elemental analyses are given in Table 2. They show that the organic additives are composed of carbon, oxygen and hydrogen with low concentrations of oxygen in the biochar compared to the biomass. The particle size of the organic additives was measured using laser granulometry (Mastersizer 3000, Malvern, Orsay, France). The results indicated that the biomass has an average particle size of $60 \mu \mathrm{m}$ while the biochar has a smaller average particle size of $20 \mu \mathrm{m}$.

\subsection{Processing of the Clay Ceramic}

The clay ceramic that was investigated in this study was produced from mixtures of clay, organic additives and water. The mixtures were made in a kneading bowl by the mixing of 
clay with $5 \mathrm{wt} . \%, 10 \mathrm{wt} . \%$ and $15 \mathrm{wt} . \%$ of organic additives. The mixtures were kneaded for 5 minutes with a gradual addition of water up to $28 \mathrm{wt} . \%$. The mixtures were then extruded using a bench extruder (Reber, Correggioverde di Dosolo, Italy) composed of a pipe and a crank activated piston. The mixtures were pushed into the pipe and released across a die as clay blocks of $60 \times 30 \times 10 \mathrm{~mm}$.

The clay blocks were subsequently dried at $25^{\circ} \mathrm{C}, 65^{\circ} \mathrm{C}$ and $105^{\circ} \mathrm{C}$ for 24 hours in an electric oven (Memmert, Schwabach, Germany). Samples were then prepared from the dried blocks by polishing with P80, P120, P180 and P280 SiC abrasive papers (CarbiMet, Buehler, Uzwil, Switzerland). Finally, the samples were fired in a sealed box, with a nitrogen flow of $5 \mathrm{~L} / \mathrm{min}$, inside of a muffle furnace (K1253, Heraeus, Hanau, Germany). The samples that were used for the X-ray diffraction and pair distribution function analyses were fired at $30^{\circ} \mathrm{C}, 600^{\circ} \mathrm{C}$, $800^{\circ} \mathrm{C}$ or $1000^{\circ} \mathrm{C}$. The other samples were fired under the same conditions at $950^{\circ} \mathrm{C}$.

\subsection{Characterization of Structure}

The atomic structure of the clay ceramic was investigated using X-Ray Diffraction (XRD) analysis. The samples in powder form were loaded in a $1 \mathrm{~mm}$ diameter polyimide capillary, which was sealed at both ends with modeling clay. The capillaries were aligned on the capillary stage of the diffractometer (D8 Discover, Bruker, Madison, WI, USA) and tested while spinning. The data were collected over a $2 \theta$ range of $2^{\circ}$ to $130^{\circ}$, with a step size of $0.05^{\circ}$, using a silver $(\mathrm{Ag})$ radiation source $(\lambda=0.56 \AA)$. The scattering of the polyimide and modeling clay was subsequently removed by subtracting a baseline that was produced from the testing of an empty capillary which was yet sealed with modeling clay. Finally, the pair distribution functions of the samples were obtained by the application of a sine Fourier transform (equation 1) to those total scattering functions $S(Q)$ in the PDFgetX2 software ${ }^{13}$ using a momentum transfer $\mathrm{Q}_{\max }$ of $15 \AA^{-1}$.

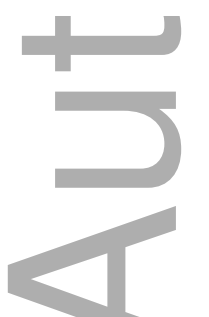

$$
\mathrm{G}(\mathrm{r})=\frac{2}{\pi} \int_{\mathrm{Q}_{\min }}^{\mathrm{Q}_{\max }} \mathrm{Q}[\mathrm{S}(\mathrm{Q})-1] \sin (\mathrm{Q} \mathrm{r}) \mathrm{dQ}
$$

The weight loss of the clay ceramic was measured as a function of temperature, using thermogravimetric analyses (TGA). Unfired samples were analyzed in the form of $200 \mathrm{mg}$ cylinders with a Q600 apparatus (TA Instruments, New Castle, DE, USA). The data were collected from $30^{\circ} \mathrm{C}$ to $1100^{\circ} \mathrm{C}$ under a nitrogen flow at a heating rate of $5^{\circ} \mathrm{C} / \mathrm{min}$. The 
percentage of organic additives was determined by subtracting the weight loss of the clay ceramic without organic additives. This was done since the thermal behavior of the organic additives within the clay ceramic is different from that out of the clay ceramic.

The porosity of the clay ceramic was determined from the measurement of the bulk density and of the true density $\left(\varepsilon=1-\rho_{\text {Bulk }} / \rho_{\text {true }}\right)$. The bulk density was measured using a balance and a caliper while the true density was measured by helium pycnometry analysis (Accupyc 1330, Micromeritics, Norcross, GA, USA) after firing at the maximum temperature of $1100{ }^{\circ} \mathrm{C}$ and grinding to eliminate the porosity.

The morphology of the organic additives and of the porosity within the clay ceramic was observed using scanning electron microscopy (XL30, Philips, Amsterdam, Netherlands). The samples were embedded in a solidifying epoxy resin and polished before the imaging under Back Scattered Imaging (BSI) conditions.

\subsection{Determination of the Thermal Properties}

The thermal properties of the clay ceramic were determined using a transitory plane source method (TPS 2500, Hot Disk AB, Gothenburg, Sweden). Duplicate samples of 30x30x5 mm were analyzed with a mica probe $(3.189 \mathrm{~mm}$ radius $)$ at $500^{\circ} \mathrm{C}$. It involved the introduction of the facility in an electrical furnace (AET Technologies, Meylan, France). Following the test, an algorithm of the Thermal Constants Analyzer software (Hot Disk AB, Gothenburg, Sweden) was used to determine the volumetric heat capacity of the clay ceramic. The specific heat capacity was subsequently determined by dividing the volumetric heat capacity by the bulk density. The bulk density of the clay ceramic was obtained from measurements of the weight and of the dimensions using a balance and a caliper.

\subsection{Determination of the Mechanical Properties}

The mechanical properties of the clay ceramic were measured by three point bending. The measurements were performed using an Instron 8548 microtester (Instron, Norwood, MA, USA) with a $50 \mathrm{~mm}$ span and a $500 \mathrm{~N}$ load cell. The specimens of 60 x 10 x $5 \mathrm{~mm}$ were loaded at a constant displacement rate of $1 \mathrm{~mm} / \mathrm{min}$ until the onset of the fracture. The flexural strength $\left(\sigma_{\mathrm{f}}\right)$ was estimated from Equation 2, where $F_{M a x}$ is the maximum force, $L$ is the loading span, $\mathrm{B}$ is the breadth, and $\mathrm{H}$ is the height of the specimens ${ }^{14}$. 


$$
\sigma_{\mathrm{f}}=\frac{3 \mathrm{~F}_{\mathrm{Max}} \mathrm{L}}{2 \mathrm{BH}^{2}}
$$

The fracture toughness/resistance-curve behavior of the clay ceramic was investigated using Single Edge Notch Bend (SENB) specimens. The SENB specimens with dimensions of 60x $10 \times 5 \mathrm{~mm}$ and notch depths of $2 \mathrm{~mm}$ ( 0.40 to 0.45 length-to-width ratio) were tested in the same Instron 8548 microtester (Instron, Norwood, MA, USA) that was used for the measurements of the flexural strength. The specimens were loaded at a displacement rate of approximately $0.1 \mathrm{~mm} / \mathrm{min}$ until pop-in was observed at the notch.

In-situ observations of cracking were carried out during the fracture experiments, using a microscope with a $5 \mathrm{X}$ magnification (MZ 8, Leica, Wetzlar, Germany). The loads were then increased in incremental stages to determine the resistance curves with procedures from the literature $^{15}$. The stress intensity factors $\left(\mathrm{K}_{\mathrm{I}}\right)$ were obtained from Equation 3, where $\sigma_{\mathrm{f}}$ is the stress at the peak load, a is the crack length, and $(\mathrm{f}(\mathrm{a} / \mathrm{w}))$ is a compliance function ${ }^{16}$.

$$
\mathrm{K}_{\mathrm{I}}=\mathrm{f}(\mathrm{a} / \mathrm{W}) \times \sigma_{\mathrm{f}} \times \sqrt{\pi \mathrm{a}}
$$

The underlying crack/microstructure interactions of the resistance-curve behavior were elucidated via in-situ optical microscopy (MZ 8, Leica, Wetzlar, Germany) and ex-situ scanning electron microscopy (XL30, Philips, Amsterdam, Netherlands) to guide the development of small/large scale crack bridging and crack trapping models.

\subsection{Thermal Reliability}

The thermal reliability of the clay ceramic was investigated via three-point bending. The specimens with dimensions of $60 \times 10 \times 5 \mathrm{~mm}$ were tested after $0,1,10$ and 100 thermal cycles. In fact, the thermal cycles were simulated by introduction and withdrawal of the specimens in a muffle furnace (K1253, Heraeus, Hanau, Germany) at $500^{\circ} \mathrm{C}$. The residual strength of the specimens was determined, as described in section 2.5.

The reason of the dependence of the residual strength on the number of thermal cycles was elucidated via scanning electron microscopy (XL30, Philips, Amsterdam, Netherlands). The observations of the fracture surfaces of the three-point bending specimens were performed 
under Secondary Electrons (SE) imaging conditions. In this way, the lengths of the effective cracks could be measured to predict the residual strengths after thermal cycles.

\section{$3 \quad$ Modeling}

\section{$3.1 \quad$ Structure}

The modeling of the structure was based on the thermal behavior of the organic additives in the clay ceramic. The thermal behavior was modeled from the Van Krevelen diagram ${ }^{17}$ by reduction of the different domains in a temperature-based equation. The concentrations of carbon, oxygen and hydrogen after the firing process were calculated as: $\mathrm{C}+\mathrm{O}+\mathrm{H}=1$ with $\mathrm{O}=\mathrm{x} . \mathrm{C}$ and $\mathrm{H}=\mathrm{y}$.C. These were also measured prior to the firing process using elemental analysis.

In this way, the weight percentages of each element that were released during the firing process were calculated as the differences between the concentrations before and after the firing process. The sum of the different weight percentages provided the weight loss of the organic additives at a given temperature. Hence, the percentage of organic additives in the clay ceramic $\left(\%_{\mathrm{T}}\right)$ was obtained from Equation 4 , using the percentage of addition $\left(\%_{\text {addition }}\right)$ and the weight loss $\left(\Delta \mathrm{m}_{(\mathrm{T})}\right)$ of the organic additives.

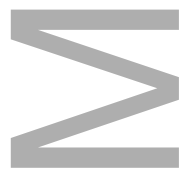

$$
\begin{gathered}
\%_{(\mathrm{T})}=\%_{\text {Addition }}-\left(\%_{\text {Addition }} \times \Delta \mathrm{m}_{(\mathrm{T})}\right) \\
\varepsilon_{(\mathrm{T})}=\varepsilon_{\text {Clay }}+\left(\%_{\text {Addition }}-\%_{(\mathrm{T})}\right)
\end{gathered}
$$

The porosity increase associated with the thermal degradation of the organic additives was regarded as equal to the difference between the percentage of organic additives before and after the firing process. In this way, the percentage of porosity at a given temperature $\left(\varepsilon_{(\mathrm{T})}\right)$ was calculated by summing the porosity from the clay $\left(\varepsilon_{\text {Clay }}\right.$ in Table 3$)$ and the porosity increase from the organic additives as shown in Equation 5.

\subsection{Specific Heat Capacity}

The specific heat capacity (c) of the clay ceramic was predicted using a rule-of-mixture approach (Equation 6). The predictions were obtained from the concentration (\% Elements) and the intrinsic properties $\left(\mathrm{C}_{\text {Elements }}\right)$ of each element. The concentrations were measured by $\mathrm{X}$ ray fluorescence analysis. On the other hand, the intrinsic properties of silicon, aluminum, 
calcium, iron, potassium and magnesium elements of the clay were collected from the literature (given in Table 3) ${ }^{18}$. A multiplicative factor of 2.16 was also used to transpose the intrinsic properties to the temperature of $500^{\circ} \mathrm{C}^{19}$.

$$
\mathrm{c}=\sum \% \%_{\text {Elements }} \times \mathrm{c}_{\text {Elements }}
$$

For the organic additives, the concentrations were obtained from the estimates of the model described in the previous section. The intrinsic properties of carbon, oxygen and hydrogen elements were also collected from the literature. They were subsequently transposed to the temperature of $500^{\circ} \mathrm{C}$ using a multiplicative factor of $1.14^{20}$. Finally, these values of the solid fraction were adapted to the clay ceramic using the previous estimates of the porosity.

\subsection{Mechanical Strength}

The mechanical strength of the clay ceramic was predicted using the damage model ${ }^{21}$ in Equation 7. The model determines the mechanical strength under a flexural loading $\left(\sigma_{\mathrm{f}}\right)$ from the damage of the clay ceramic (D) and the intrinsic strength of the clay $\left(\sigma_{\text {Clay }}\right)$.

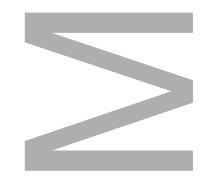

$$
\sigma_{\mathrm{f}}=(1-\mathrm{D}) \sigma_{\text {Clay }}
$$

The intrinsic strength of the clay was regarded as equal to $37.0 \mathrm{MPa}$. This value was obtained from the mechanical strength of the clay ceramic without organic additives. On the other hand, the damage of the clay ceramic was estimated from Equation $8^{22}$, where $\%$ Defects is the sum of the percentages of porosity and organic additives and $\phi$ is the median defect size.

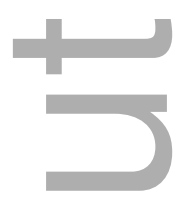

$$
\mathrm{D}=\frac{2^{\phi}}{2^{\phi-1}}\left[1-\frac{1}{\left(1+\%_{\text {Defects }}\right)^{\phi}}\right]
$$

The median defect size relates the percentage of defects to their effective impact on the damage. In fact, the impact of the large pores was regarded as equal to that of a greater volume fraction of small pores. It was obtained from the particle size distribution of the organic additives with the estimates of the structure described in section 3.1 (see Table 3).

\subsection{Fracture Toughness}


The fracture toughness/resistance-curve $\left(K_{R}\right)$ estimates of the clay ceramic were obtained from the sum of the initiation fracture toughness $\left(\mathrm{K}_{\mathrm{I}}\right)$ and the toughening due to the observed crack-tip shielding mechanisms ${ }^{23}$. The crack-tip shielding mechanisms included small/large scale bridging $\left(\mathrm{K}_{\mathrm{B}}\right)$ and crack trapping $\left(\mathrm{K}_{\mathrm{T}}\right)$ as shown in Equation 9.

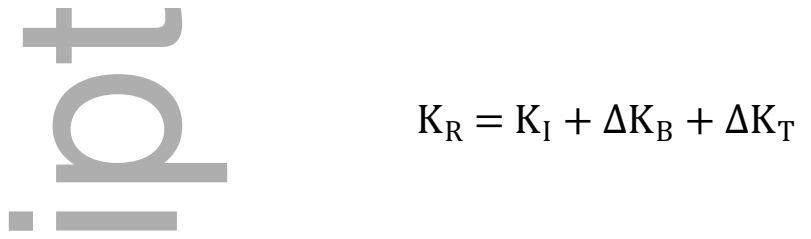

The toughening due to crack bridging was predicted by a small-scale approach ${ }^{24}$ for crack extensions smaller than $0.5 \mathrm{~mm}$ and by a large-scale approach ${ }^{25}$ for crack extensions larger than $0.5 \mathrm{~mm}$. The predictions of the small-scale bridging contribution $\left(\Delta \mathrm{K}_{\mathrm{SSB}}\right)$ were obtained from Equation 10, where $V_{B}$ is the fraction of bridging ligaments, $L$ is the distance from the crack-tip to the last unfractured ligament, $\mathrm{x}$ is the distance from the crack-tip and $\sigma_{\mathrm{f}}$ is the strength of the bridging ligaments. The predictions of the large-scale bridging contribution $\left(\Delta \mathrm{K}_{\mathrm{LSB}}\right)$ were obtained from Equation 11, where $\mathrm{h}(\mathrm{a}, \mathrm{x})$ is a weight function (see Table 3$)^{26}$.

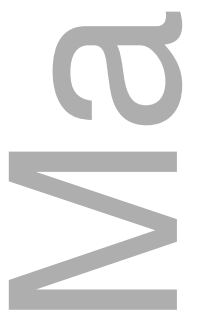

$$
\begin{gathered}
\Delta \mathrm{K}_{\mathrm{SSB}}=\mathrm{V}_{\mathrm{B}} \sqrt{\frac{2}{\pi}} \int_{0}^{\mathrm{L}} \frac{\sigma_{\mathrm{f}}}{\sqrt{\mathrm{x}}} \mathrm{dx} \\
\Delta \mathrm{K}_{\mathrm{LSB}}=\mathrm{V}_{\mathrm{B}} \int_{0}^{\mathrm{L}} \sigma_{\mathrm{f}} \mathrm{h}(\mathrm{a}, \mathrm{x}) \mathrm{dx} \\
\Delta \mathrm{K}_{\mathrm{T}}=\mathrm{K}_{\mathrm{I}}\left[\left(1-2 \frac{\mathrm{R}}{\mathrm{L}}\right)+\left(2.1+4.8 \frac{\mathrm{R}}{\mathrm{L}}\right)^{2} \frac{2 \mathrm{R}}{\%_{(\mathrm{T})}}\right]
\end{gathered}
$$

The toughening due to crack trapping corresponds to the action of the particles of organic additives on crack propagation. The predictions of the crack trapping contribution were then obtained using the model $^{27}$ in Equation 12, where $\mathrm{R}$ is the radius of the particles, $\mathrm{L}$ is the distance between the particles and $\%_{(\mathrm{T})}$ is the percentage of particles. It is important to note that the parameters of the crack-tip shielding models were all estimated from the optical and SEM images of the underlying crack/microstructure interactions.

\subsection{Thermal Reliability}

The residual strengths of the clay ceramics were predicted from observations of the cracks in the fractured three-point bending specimens after thermal cycles. The estimates were obtained 
using Equation 13, where $\sigma_{\mathrm{r}}$ is the residual strength of the clay ceramic, $\mathrm{K}_{\mathrm{c}}$ is the critical fracture toughness of the clay ceramic, $\mathrm{F}$ is the boundary correction factor of the effective crack, $\mathrm{Q}$ is the shape factor of the effective crack, and a is the length of the effective crack $(\text { see Table } 3)^{28}$.

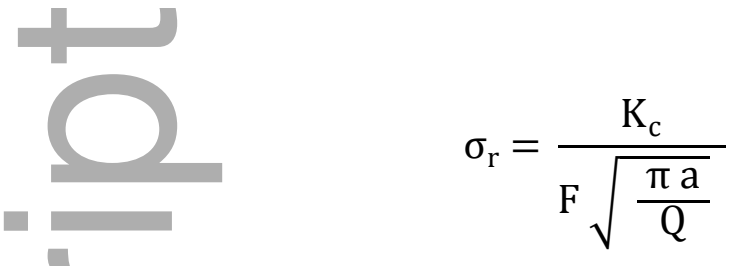

The boundary correction factor that was used is a specific factor for semi-elliptical surface cracks. It is given by Equation 14 , where $\mathrm{M}_{1}, \mathrm{M}_{2}, \mathrm{M}_{3}$ and $\mathrm{g}$ are curve fitting functions, $\mathrm{f}_{\phi}$ is an angular function, $\mathrm{f}_{\mathrm{W}}$ is a finite-width correction factor, $\mathrm{t}$ is the thickness of the plan, and a is the length of the effective $\mathrm{crack}^{29}$.

$$
F=\left[M_{1}+M_{2}\left(\frac{a}{t}\right)^{2}+M_{3}\left(\frac{a}{t}\right)^{4}\right] g f_{\phi} f_{W}
$$

The curve fitting functions that are used in Equation 14 were estimated from the ratio of the crack depth to the crack length $(\mathrm{a} / \mathrm{c})$. The estimates were all obtained for a ratio smaller than 1. The determination of the curve fitting functions also included the parametric angle of the ellipse $(\phi)$. Note that the a/c ratio and the parametric angle of the ellipse were both estimated from the observations of the effective cracks.

\section{$4 \quad$ Results and Discussion}

\subsection{Structure}

\subsubsection{Atomic Structure}

The X-ray pair distribution functions (PDFs) of the clay ceramic with a 15 wt.\% addition of biochar are shown in Figure 1. The atom-atom correlations indicate that the clay ceramic is composed of clay minerals (see section 2.1 ) prior to firing (i.e., at $30^{\circ} \mathrm{C}$ ). The tetrahedral sheets are represented by the Si-O correlation at $1.52 \AA$ and the larger atom-atom distances at $4.24 \AA$ and $7.44 \AA^{30}$. The Al-O bonds of the octahedral sheets are also represented by the peaks at $1.92 \AA, 3.71 \AA$, and $9.11 \AA$. Furthermore, the distances between the silicon and aluminum atoms (Si-Al) are observed in the PDF curve at $3.10 \AA, 5.24 \AA$ and $8.10 \AA$. 
The PDF curve obtained after firing at $600^{\circ} \mathrm{C}$ shows some changes in the intensities of the peaks. In fact, the clay minerals are subjected to dehydroxylation at temperatures between $450^{\circ} \mathrm{C}$ and $600^{\circ} \mathrm{C}^{31,32}$. The transition from VI coordinated aluminum atoms to predominantly IV coordinated aluminum atoms decreases the intensities of the Al-O correlations at $1.92 \AA$, $3.71 \AA$ and $9.11 \AA$. The formation of tetrahedrally-coordinated aluminum sites also results in an increase of the intensity in the original Si-O correlations at $1.52 \AA, 4.24 \AA$ and $7.44 \AA$.

After firing at $800^{\circ} \mathrm{C}$, the PDF curve shows some changes in the $\mathrm{r}$ spacing of the atom-atom correlations. The transformation of the Al-Si correlation at $8.10 \AA$ into a $\mathrm{Ca}-\mathrm{Al}$ correlation at $8.45 \AA$ corresponds to a combination of aluminum atoms from the octahedral sheets with calcium atoms from calcite $\left(\mathrm{CaCO}_{3}\right)$ to form gehlenite $\left(\mathrm{Ca}_{2} \mathrm{Al}_{2} \mathrm{SiO}_{7}\right)^{33}$. A combination of the silicon atoms from the tetrahedral sheets with the remaining atoms of calcium into wollastonite $\left(\mathrm{CaSiO}_{3}\right)$ is also visible in the PDF curve with a transformation of the Al-Si correlation at $5.24 \AA$ into a Ca-Si correlation at $4.87 \AA^{34}$. This incorporation of the octahedral and tetrahedral sheets of the clay minerals in gehlenite and wollastonite is completed after firing at $1000^{\circ} \mathrm{C}$. The incorporation occurs via limited rearrangement of the silicon and aluminum atoms due to similar atom-atom distances between the clay minerals and these calcium alumino-silicates.

The PDF curves also show the presence of biochar with a C-C correlation of the aromatic cycles at $2.15 \AA^{35}$. The intensity of the peak remains the same after firing at $30^{\circ} \mathrm{C}, 600^{\circ} \mathrm{C}$, $800^{\circ} \mathrm{C}$ and $1000^{\circ} \mathrm{C}$. Hence, the biochar is not affected by the temperature due to firing in the nitrogen atmosphere. The $\mathrm{r}$ spacing of the $\mathrm{C}-\mathrm{C}$ correlation also remains the same with the firing temperatures. This means that no interaction occurs between the biochar and the clay minerals during the firing process. In fact, the clay ceramic investigated in this study only correspond to a matrix of calcium-alumino silicates enclosing organic additives.

\subsubsection{Percentage of Organic Additives}

The dependence of the percentage of organic additives on the firing temperature of the clay ceramic is displayed in Figure 2. The biomass, composed of carbon, oxygen and hydrogen elements transforms by pyrolysis ${ }^{36}$ into $\mathrm{CO}, \mathrm{CO}_{2}, \mathrm{CH}_{4}$ and $\mathrm{H}_{2}$, whose release induces a porosity increase of the clay ceramic. But the biochar, which is composed of carbon and hydrogen elements, only transforms into $\mathrm{CH}_{4}$ and $\mathrm{H}_{2}$ at high temperatures. The clay ceramic with a $15 \mathrm{wt} . \%$ addition of biochar has then a high percentage of organic additives of $14 \mathrm{wt} . \%$ and a low porosity increase of $1 \mathrm{vol} . \%$ after firing at the temperature of $950^{\circ} \mathrm{C}$. 
The thermal behavior of other organic additives, such as wood, peat and coal is predicted from the Van Krevelen Diagram. The predictions obtained from the modeling also provide information for a larger addition of organic additives. In fact, the clay ceramic with a $30 \mathrm{wt} \%$ addition of biochar should contain up to 27 wt.\% of organic additives after firing at the temperature of $950^{\circ} \mathrm{C}$.

\subsubsection{Morphology of Organic Additives}

The SEM micrographs of the clay ceramic obtained after firing at $950^{\circ} \mathrm{C}$ are presented in Figure 3. The clay ceramic without organic additives has a heterogeneous structure of clay with pores and quartz particles. The pores correspond to the air retained in the clay ceramic during the extrusion process. These $10 \pm 2 \mu \mathrm{m}$ pores are minor defects in the structure of the clay ceramic. In fact, the major defects of the structure remain the decohesions around the quartz particles with dimensions of $50 \pm 20 \mu \mathrm{m}$ that are equivalent to the dimensions of the particles. These decohesions result from the larger shrinkage of quartz than that of the clay matrix during the $\beta \rightarrow \alpha$ quartz inversion of the cooling.

The clay ceramic with a $15 \mathrm{wt} . \%$ addition of biomass has a greater heterogeneity than that of the clay ceramic without organic additives. The $60 \mu \mathrm{m}$ particles of the biomass appear as the largest defects of the clay ceramic after firing at a temperature of $950^{\circ} \mathrm{C}$. However, the clay ceramic with a 15 wt.\% addition of biochar has a lower heterogeneity than that of the clay ceramic without organic additives. The biochar particles are minor defects compared to the 50 $\mu \mathrm{m}$ decohesions around the quartz particles.

\subsection{Specific Heat Capacity}

The dependence of the specific heat capacity of the clay ceramic on the percentage of organic additives is displayed in Figure 4. The clay ceramic without organic additives has a specific heat capacity of $1.20 \pm 0.02 \mathrm{~kJ} / \mathrm{kg} . \mathrm{K}$ after a firing process at $950^{\circ} \mathrm{C}$. This relatively high specific heat capacity compared to that of other ceramic materials ${ }^{37}$ is attributed to the high concentration of alkali metals along with the relatively low percentage of porosity (i.e., 23 vol.\%). On the other hand, the relatively low uncertainty in the results of the specific heat capacity is due to the absolute nature of the measurements (transient plane source technique).

The biomass transform into gas, which the release induces a porosity increase of the clay ceramic during the firing process. The specific heat capacity of the clay ceramic is then decreased by $3 \%$ using a $15 \mathrm{wt} . \%$ addition of biomass. However, the biochar is conserved in 
the clay ceramic during the firing process. The specific heat capacity of the clay ceramic is then increased by $12 \%$ in the case of a 15 wt. $\%$ addition of biochar. Therefore, the clay ceramic with a $15 \mathrm{wt} . \%$ addition of biochar has a specific heat capacity of $1.35 \pm 0.02 \mathrm{~kJ} / \mathrm{kg} . \mathrm{K}$ after firing at $950^{\circ} \mathrm{C}$. It is important to note that the conservation of the biochar prevents a significant decrease in the bulk density of the clay ceramic. Hence, the improvement of the volumetric heat capacity is equivalent to that of the specific heat capacity.

The modeling of the specific heat capacity also provides information for a larger addition of organic additives. In fact, the results obtained from the previous calculations of the elemental composition (after the firing process), along with values from the literature of the specific heat capacity of each element, indicate that the specific heat capacity of the clay ceramic should increase up to $1.49 \mathrm{~kJ} / \mathrm{kg}$.K for a $30 \mathrm{wt}$ \% addition of biochar. Such a high specific heat capacity is very promising for thermal energy storage. It means that the clay ceramic with a $30 \mathrm{wt} . \%$ addition of biochar could be as efficient as molten salts with the added benefit of an ease of use in the physical form of bricks.

\subsection{Mechanical Strength}

The dependence of the mechanical/flexural strength on the percentage of organic additives is presented in Figure 5. The clay ceramic without organic additives has a mechanical strength of $18.9 \pm 0.9 \mathrm{MPa}$ after a firing process at $950^{\circ} \mathrm{C}$. The mechanical strength depends on the sintering process and the bonding of the clay particles as well as the $50 \mu \mathrm{m}$ defects around the quartz particles that initiate fracture.

The addition of organic additives in the clay ceramic induces a decrease of the mechanical strength. However, the severity of the decrease depends on the particle size of the organic additives. The $60 \mu \mathrm{m}$ particles of the biomass correspond to the largest defects of the clay ceramic. The mechanical strength of the clay ceramic is then decreased by $37 \%$ in case of a $15 \mathrm{wt} . \%$ addition of biomass. On the other hand, the $20 \mu \mathrm{m}$ particles of the biochar represent minor defects in the clay ceramic. The mechanical strength is then only decreased by $16 \%$ using a $15 \mathrm{wt} \%$ addition of biochar. Therefore, the clay ceramic with a $15 \mathrm{wt} \%$ addition of biochar conserves a high mechanical strength of $15.8 \pm 0.5 \mathrm{MPa}$ after firing at $950^{\circ} \mathrm{C}$. The dispersion in the mechanical strength of the clay ceramic (i.e., 0.5 MPa) is also reduced compared to that of the clay ceramic without organic additives (i.e., 0.9 MPa) due to the reduction in the heterogeneity of the structure. 
The predictions of the damage model (Equations 7 and 8) are consistent with the results of the measurements. They also provide information for a larger addition of organic additives in the clay ceramic. In fact, the clay ceramic could have a mechanical strength of $11.1 \mathrm{MPa}$ in the case of a $30 \mathrm{wt} . \%$ addition of biochar.

\subsection{Resistance-Curve Behavior}

The measured and predicted resistance-curve behavior are presented in Figure 6. The clay ceramic without organic additives has an initiation fracture toughness of $1.7 \mathrm{MPa} / \mathrm{m}$. The fracture toughness of the clay ceramic also increases to $2.0 \mathrm{MPa} / \mathrm{m}$ for a crack extension of $1.6 \mathrm{~mm}$. This increase in the fracture toughness is due to toughening by crack bridging, as shown in Figure 7.

The addition of organic additives in the clay ceramic results in a decrease of the initiation fracture toughness. In fact, the particles of organic additives act as initiators of fracture in the clay ceramic. The $60 \mu \mathrm{m}$ particles of the biomass decrease the initiation fracture toughness to 1.1 MPa $\sqrt{\mathrm{m}}$ in the case of a $15 \mathrm{wt} . \%$ addition. However, the initiation fracture toughness is only decreased to $1.3 \mathrm{MPa} \sqrt{ } \mathrm{m}$ for a $15 \mathrm{wt} . \%$ addition of biochar with small $20 \mu \mathrm{m}$ particles.

The clay ceramic with organic additives is also toughened by crack trapping, as observed in Figure 7. The combination of crack bridging and crack trapping mechanisms increases the fracture toughness of the clay ceramic with a $15 \mathrm{wt} . \%$ addition of biomass to $1.5 \mathrm{MPa} \sqrt{\mathrm{m}}$. On the other hand, the fracture toughness of the clay ceramic increases up to $1.7 \mathrm{MPa} \sqrt{\mathrm{m}}$ using a 15 wt. $\%$ addition of biochar.

\subsection{Thermal Reliability}

The dependence of the flexural strength on the number of thermal cycles is presented in Figure 8. The clay ceramic without organic additives has a flexural strength of $18.9 \mathrm{MPa}$ after 0 thermal cycles. The flexural strength also decreases to 19.1 MPa, 17.6 MPa and 14.8 MPa after 1, 10 and 100 thermal cycles. The decrease in the flexural strength is due to thermal fatigue. In fact, the thermal expansion mismatch between the constituents generates some cyclic stress concentration that lead to crack extension and fracture. This results in a $21 \%$ decrease of the flexural strength after 100 thermal cycles.

The addition of organic additives decreases the flexural strength before thermal cycling (see section 4.3). The flexural strength also decreases with the thermal cycles, compared to that of the clay ceramic without organic additives, due to a lower initiation fracture toughness (see 
section 4.4). However, the extra toughening (i.e., crack trapping) associated with the particles of organic additives also limits the crack extension, which contributes to a conservation of the flexural strength with the thermal cycles. The flexural strength only decreases by $26 \%$ after 100 thermal cycles in case of a 15 wt.\% addition of biomass. Similarly, the crack extension for the clay ceramic with a $15 \mathrm{wt} . \%$ addition of biochar only results in a $23 \%$ decrease of the flexural strength after 100 thermal cycles.

It is important to note that the measured and predicted strengths of the clay ceramics are comparable after different thermal cycles. In fact, the results of both the measurements and the modeling indicate that the clay ceramic with a $15 \mathrm{wt} \%$ addition of biochar conserves a high residual strength of $12.1 \mathrm{MPa}$ after 100 thermal cycles. This means that the clay/biochar ceramics can be considered as thermally reliable materials for a use in thermal energy storage.

\subsection{Implications}

The implications of this research are significant for the use of ceramic materials in thermal energy storage. Thermal energy storage can be performed using ceramic materials or molten salts. However, molten salts remain the most widely used medium in thermal energy storage due to their high specific heat capacities between $1.10 \mathrm{~kJ} / \mathrm{kg} . \mathrm{K}$ and $1.50 \mathrm{~kJ} / \mathrm{kg} . \mathrm{K}$.

This work shows that the specific heat capacities of ceramic materials can be improved up to $1.49 \mathrm{~kJ} / \mathrm{kg} . \mathrm{K}$ by the control of structure, via the addition of biochar. This means that $24 \%$ more energy can be stored in clay/biochar ceramics than in the same mass of conventional ceramics. The specific heat capacities of such ceramic materials are then comparable to the specific heat capacities of molten salts that are currently used in thermal energy storage.

Moreover, the clay/biochar ceramics in the physical form of bricks are much easier to use than molten salts. The clay/biochar ceramics are also thermally reliable materials with a significant strength after thermal cycles. This combination of specific heat capacity and flexural strength makes the clay/biochar ceramics one of the most appropriate materials for thermal energy storage. The valorization of biochar, which is a by-product from the thermal conversion of wood, also minimizes the economical and environmental cost of the materials.

\section{Conclusions}

In this paper, the structure-property relationship of a clay ceramic with organic additives (biomass and biochar) is investigated to develop an alternative material for thermal energy storage. Salient conclusions arising from this study are summarized below. 
1. The atomic structure of the clay ceramic with organic additives transformed into calcium alumino-silicates during the firing process. However, the organic additives remained at the macroscopic scale without any interaction with the matrix at temperatures up to $1000^{\circ} \mathrm{C}$.

2. The specific heat capacity decreased in the case of organic additives with high oxygen concentrations (biomass) due to a porosity formation. However, the conservation of the organic additives with low oxygen concentrations (biochar) resulted in an increase of the specific heat capacity up to $1.49 \mathrm{~kJ} / \mathrm{kg} . \mathrm{K}$.

3. The flexural strength decreased in the case of organic additives with a large particle size (biomass) due to stress concentration effects. However, the organic additives with small particles (biochar) resulted in a minor degradation of the flexural strength and fracture toughness. The extra toughening associated with the particles of organic additives also contributed to the conservation of the thermal reliability.

4. The clay ceramic with a 30 wt.\% addition of biochar had a comparable specific heat capacity to that of molten salts that are currently used in thermal energy storage. In addition, the clay/biochar ceramics offered the added benefit of an ease of use in the physical form of bricks.

\section{Acknowledgments}

The authors would like to acknowledge the CARNOT Mines Institute and the RAPSODEE Center at Ecole des Mines d'Albi for financial support. The authors are also grateful to the management and staff of the Department of Mechanical and Aerospace Engineering, and the Department of Civil and Environmental Engineering, and the Andlinger Center for Energy and the Environment at Princeton University, for their assistance with the research.

\section{$7 \quad$ Funding}

This study was funded by Institut CARNOT Mines (CARNOT 2013).

\section{Conflict of interest}

The authors declare that they do not have any conflict of interest.

\section{References}

1. J.P. Barton and D.G. Infield, "Energy storage and its use with intermittent renewable energy," IEEE Trans. Energy Convers., 19 [2] 441-448 (2004). 
2. B. Dunn, H. Kamath, and J. M. Tarascon, "Electrical energy storage for the grid: a battery of choices," Science, 334 [6058] 928-935 (2011).

3. S. Rehman, L. M. Al-Hadhrami, and M. M. Alam, "Pumped hydro energy storage system: a technological review," Renew. Sust. Energ. Rev., 44 586-598 (2015).

4. H. Ibrahim, A. Ilinca, and J. Perron, "Energy storage systems - characteristics and comparisons," Renew. Sust. Energ. Rev., 12 [5] 1221-1250 (2008).

5. S. Kuravi, J. Trahan, D. Y. Goswami, M. M. Rahman, and E. K. Stefanakos, "Thermal energy storage technologies and systems for concentrating solar power plants," Prog. Ener. Combust., 39 [4] 285-319 (2013).

6. M. Aneke and M. Wang, "Energy storage technologies and real life applications - A state of the art review," Appl. Energy, 179 350-377 (2016).

7. G. Li and X. Zheng, "Thermal energy storage system integration forms for a sustainable future," Renew. Sust. Energ. Rev., 62 736-757 (2016).

8. U. Herrmann, B. Kelly, and H. Price, "Two-tank molten salt storage for parabolic trough solar power plants," Energy, 29 [5-6] 883-893 (2004).

9. E. John, M. Hale, and P. Selvam, "Concrete as a thermal energy storage medium for thermocline solar energy storage systems," Sol. Energy, 96 94-204 (2013).

10. K. Willam, I. Rhee, and Y. Xi, "Thermal degradation of heterogeneous concrete materials," J. Mater. Civ. Eng., 17 [3] 276-285 (2005).

11. W. M. Carty and U. Senapati, "Porcelain-raw materials, processing, phase evolution, and mechanical behavior," J. Am. Ceram. Soc., 81 [1] 3-20 (1998).

12. D. Laing, W. D. Steinmann, R. Tamme, and C. Richter, "Solid media thermal storage for parabolic trough power plants," Sol. Energy, 80 [10] 1283-1289 (2006).

13. X. Qiu, J. W. Thompson, and S. J. L. Billinge, "PDFgetX2: a GUI-driven program to obtain the pair distribution function from X-ray powder diffraction data," J. Appl. Cryst., 37 678-678 (2004).

14. "Standard test methods for flexural properties of unreinforced and reinforced plastics and electrical insulating materials," American Society for Testing and Materials, D790-10, 2010.

15. W. O. Soboyejo, Mechanical properties of engineered materials; pp. 414-455. CRC Press, Mechanical Engineering (Marcel Dekker), 2002.

16. "Standard test method for plane-strain fracture toughness of metallic materials," American Society for Testing and Materials, E399-90, 1997.

17. D. W. van Krevelen, "Graphical-statistical method for the study of structure and reaction processes of coal," Fuel, 29 269-284 (1950). 
18. D. R. Lide, Handbook of chemistry and physics. CRC Press, 2009.

19. H. Wen, J. Lu, Y. Xiao, and J. Deng, "Temperature dependence of thermal conductivity, diffusion and specific heat capacity for coal and rocks from coalfield," Thermochim. Acta, 619 41-47 (2015).

20. C. Dupont, R. Chiriac, G. Gauthier, and F. Toche, "Heat capacity measurements of various biomass types and pyrolysis residues," Fuel, 115 644-651 (2014).

21. E. A. Dean and J. A. Lopez, "Empirical dependence of elastic moduli on porosity for ceramic materials," J. Am. Ceram. Soc., 66 [5] 366-370 (1983).

22. A. Sugarawa and Y. Yoshizawa, "An investigation on the thermal conductivity of porous materials and its application to porous rock," Austr. J. Phys., 14 469-480 (1961).

23. A. G. Evans and K. T. Faber, "Crack-growth resistance of microcracking brittle materials," J. Am. Ceram. Soc., 67 [4] 255-260 (1984).

24. B. Budiansky, J. C. Amazigo, and A. G. Evans, "Small-scale crack bridging and the fracture toughness of particulate-reinforced ceramics," J. Mech. Phys. Solids, 36 [2] 167-187 (1988).

25. D. R. Bloyer, R. O. Ritchie, and K. T. Venkatesvara Rao, "Fracture toughness and Rcurve behavior of laminated brittle-matrix composites," Metall. Mater. Trans. A, 29 [10] 2483-2496 (1998).

26. T. Fett and D. Munz, "Stress intensity factors and weight functions for one-dimensional cracks", Kernforschungszentrum Karlsruhe Institut für Materialforschung, Rept. No. KFK 5290, December 1994.

27. T. M. Mower and A. S. Argon, "Experimental investigations of crack trapping in brittle heterogeneous solids," Mech. Mater., 19 [4] 343-364 (1995).

28. X. Wang, "Stress intensity factors and weight functions for deep semi-elliptical surface cracks in finite-thickness plates," Fatigue Fract. Eng. M., 25 [3] 291-304 (2002).

29. J. C. Newman and I. S. Raju, "An empirical stress-intensity factor equation for surface crack," Eng. Fract. Mech., 15 [1-2] 185-192 (1981).

30. A. E. Morandeau and C. E. White, "In situ X-ray pair distribution function analysis of accelerated carbonation of a synthetic calcium-silicate-hydrate gel," J. Mater. Chem. A, 3 [16] 8597-8605 (2015).

31. C. E. White, J. L. Provis, T. Proffen, D. P. Riley, and J. S. J. van Deventer, "Density functional modeling of the local structure of kaolinite subjected to thermal dehydroxylation," J. Phys. Chem. A, 114 [14] 4988-4996 (2010). 
32. R. Fernandez, F. Martirena, and K. L. Scrivener, "The origin of the pozzolanic activity of calcined clay minerals: a comparison between kaolinite, illite and montmorillonite," Cem. Concr. Res., 41 [1] 113-122 (2011).

33. T. Peters and R. Iberg, "Mineralogical changes during firing of calcium-rich brick clays," Am. Ceram. Soc. Bull., 57 [5] 503-509 (1978).

34. G. Cultrone, C. Rodriguez-Navarro, E. Sebastian, O. Cazalla, and M. J. De La Torre, «Carbonate and silicate phase reactions during ceramic firing," Eur. J. Mineral., 13 [3] 621$634(2001)$.

35. V. Petkov, Y. Ren, S. Kabekkodu, and D. Murphy, "Atomic pair distribution functions analysis of disordered low-Z materials," Phys. Chem. Chem. Phys., 15 [22] 8544-8554 (2013). 36. C. Di Blasi, "Modeling chemical and physical processes of wood and biomass pyrolysis," Prog. Energy Combust. Sci., 34 [1] 47-90 (2008).

37. A. Meffre, X. Py, R. Olives, C. Bessada, E. Veron, and P. Echegut, "High-temperature sensible heat-based thermal energy storage materials made of vitrified MSWI fly ashes," Waste Biomass Valor., 6 1003-1014 (2015).

\section{Figure Caption List}

Figure 1: $\mathrm{X}$-ray pair distribution function curves of the clay ceramic with a $15 \mathrm{wt} \%$ addition of biochar after firing at $30^{\circ} \mathrm{C}, 600^{\circ} \mathrm{C}, 800^{\circ} \mathrm{C}$ and $1000^{\circ} \mathrm{C}$.

Figure 2: Dependence of the percentage of organic additive on the firing temperature of the clay ceramic with a $15 \mathrm{wt} . \%$ addition of biomass and biochar in a nitrogen atmosphere.

Figure 3: SEM micrographs of the clay ceramic (a), clay ceramic with a 15 wt.\% addition of biomass (b), clay ceramic with a 15 wt. \% addition of biochar (c), after firing at $950^{\circ} \mathrm{C}$.

Figure 4: Dependence of the specific heat capacity of the clay ceramic on the percentage of organic additives after firing at $950^{\circ} \mathrm{C}$.

Figure 5: Dependence of the flexural strength of the clay ceramic on the percentage of organic additives after firing at $950^{\circ} \mathrm{C}$.

Figure 6: Resistance-curve behavior of the clay ceramic and of the clay ceramic with a 15 wt. $\%$ addition of biomass and biochar after firing at $950^{\circ} \mathrm{C}$.

Figure 7: SEM micrographs of the crack-tip shielding mechanisms of the clay ceramic (a) and of the clay ceramic with a 15 wt.\% addition of biomass (b) and biochar (c) after firing at $950^{\circ} \mathrm{C}$.

Figure 8: Dependence of the residual strength of the clay ceramic and of the clay ceramic with a $15 \mathrm{wt} . \%$ addition of biomass and biochar on the number of thermal cycles at $500^{\circ} \mathrm{C}$. 


\begin{tabular}{ccccccc}
\hline \multirow{2}{*}{ Sample } & \multicolumn{7}{c}{ Concentration (wt.\%) } \\
\cline { 2 - 7 } & $\mathrm{SiO}_{2}$ & $\mathrm{Al}_{2} \mathrm{O}_{3}$ & $\mathrm{CaO}$ & $\mathrm{Fe}_{2} \mathrm{O}_{3}$ & $\mathrm{~K}_{2} \mathrm{O}$ & $\mathrm{MgO}$ \\
\hline \multirow{2}{*}{ Clay } & 57.1 & 14.5 & 8.92 & 6.20 & 3.04 & 2.21 \\
\hline & & & & & &
\end{tabular}

Table 1: Elemental composition of the clay with the concentrations in silicon, aluminum, calcium, iron, potassium and magnesium oxides.

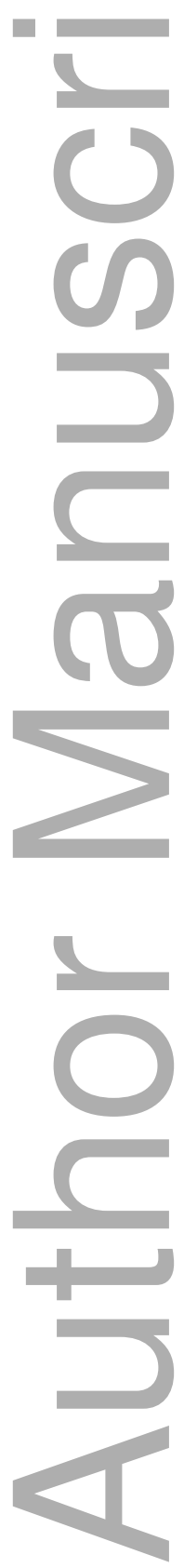




\begin{tabular}{cccccc}
\hline \multirow{2}{*}{ Sample } & \multicolumn{5}{c}{ Concentration (wt.\%) } \\
\cline { 2 - 6 } & $\mathrm{C}$ & $\mathrm{H}$ & $\mathrm{O}$ & $\mathrm{N}$ & $\mathrm{S}$ \\
\hline Biomass & 49.5 & 6.8 & 42.4 & 0.2 & 0.0 \\
Biochar & 84.9 & 4.0 & 9.8 & 0.5 & 0.0 \\
\hline
\end{tabular}

Table 2: Elemental composition of the organic additives with the concentrations in carbon, hydrogen, oxygen, nitrogen and sulfur elements.

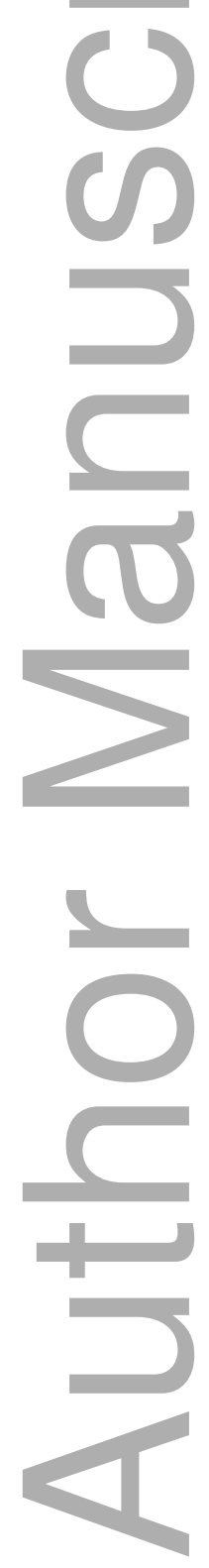




\begin{tabular}{|c|c|c|c|}
\hline Model & Equation & Inputs & Origin \\
\hline \multirow{9}{*}{$\begin{array}{l}\text { Specific he } \\
\text { capacity }\end{array}$} & \multirow{9}{*}{6} & $\mathrm{c}_{\mathrm{Si}}=0.71 \mathrm{~kJ} / \mathrm{kg} \cdot \mathrm{K}$ & \multirow{9}{*}{ Literature } \\
\hline & & $\mathrm{c}_{\mathrm{Al}}=0.90 \mathrm{~kJ} / \mathrm{kg} \cdot \mathrm{K}$ & \\
\hline & & $\mathrm{c}_{\mathrm{Ca}}=0.65 \mathrm{~kJ} / \mathrm{kg} \cdot \mathrm{K}$ & \\
\hline & & $\mathrm{c}_{\mathrm{Fe}}=0.45 \mathrm{~kJ} / \mathrm{kg} \cdot \mathrm{K}$ & \\
\hline & & $\mathrm{c}_{\mathrm{K}}=0.76 \mathrm{~kJ} / \mathrm{kg} \cdot \mathrm{K}$ & \\
\hline & & $\mathrm{c}_{\mathrm{Mg}}=1.02 \mathrm{~kJ} / \mathrm{kg} \cdot \mathrm{K}$ & \\
\hline & & $c_{C}=0.71 \mathrm{~kJ} / \mathrm{kg} . \mathrm{K}$ & \\
\hline & & $c_{\mathrm{O}}=0.92 \mathrm{~kJ} / \mathrm{kg} . \mathrm{K}$ & \\
\hline & & $\mathrm{c}_{\mathrm{H}}=14.30 \mathrm{~kJ} / \mathrm{kg} \cdot \mathrm{K}$ & \\
\hline \multirow{3}{*}{$\begin{array}{l}\text { Mechanica } \\
\text { strength }\end{array}$} & \multirow{3}{*}{7,8} & $\sigma_{\text {Clay }}=37.0 \mathrm{MPa}$ & \multirow{3}{*}{ Experiments } \\
\hline & & $\varepsilon_{\text {Clay }}=23$ vol. $\%$ & \\
\hline & & $\phi_{\text {Clay }}=50 \mu \mathrm{m}$ & \\
\hline \multirow{14}{*}{$\begin{array}{l}\text { Fracture } \\
\text { toughness }\end{array}$} & \multirow{14}{*}{$9,10,11,12$} & $\mathrm{~h}_{[0 ; 0]}=0.4980 \quad \mathrm{~h}_{[1 ; 3]}=-32.7208$ & \multirow{8}{*}{ Literature } \\
\hline & & $\mathrm{h}_{[0 ; 1]}=2.4463 \quad \mathrm{~h}_{[1 ; 4]}=18.1214$ & \\
\hline & & $\mathrm{h}_{[0 ; 2]}=0.0700 \quad \mathrm{~h}_{[2 ; 0]}=-0.1927$ & \\
\hline & & $\mathrm{h}_{[0 ; 3]}=1.3187 \quad \mathrm{~h}_{[2 ; 1]}=2.55863$ & \\
\hline & & $h_{[0 ; 4]}=-3.0670 \quad h_{[2 ; 2]}=-12.6415$ & \\
\hline & & $\mathrm{h}_{[1 ; 0]}=0.5416 \quad \mathrm{~h}_{[2 ; 3]}=19.7630$ & \\
\hline & & $h_{[1 ; 1]}=-5.0806 \quad h_{[2 ; 4]}=-10.9860$ & \\
\hline & & $\mathrm{h}_{[1 ; 2]}=24.3447$ & \\
\hline & & $\mathrm{V}_{\mathrm{B}}=5 \mathrm{vol} . \%$ & \multirow{6}{*}{ Experiments } \\
\hline & & $\sigma_{\mathrm{f}}=8.7 \mathrm{MPa}$ & \\
\hline & & $\mathrm{R}_{\text {Biomass }}=30 \mu \mathrm{m}$ & \\
\hline & & $\mathrm{L}_{\text {Biomass }}=150 \mu \mathrm{m}$ & \\
\hline & & $\mathrm{R}_{\text {Biochar }}=10 \mu \mathrm{m}$ & \\
\hline & & $\mathrm{L}_{\text {Biochar }}=50 \mu \mathrm{m}$ & \\
\hline \multirow{3}{*}{$\begin{array}{l}\text { Thermal } \\
\text { reliability }\end{array}$} & & $\mathrm{K}_{\mathrm{C}}=2.0 \mathrm{MPa} \sqrt{\mathrm{m}}_{\mathrm{m}}$ (Clay) & \multirow{3}{*}{ Experiments } \\
\hline & 13,14 & $\mathrm{~K}_{\mathrm{C}}=1.3 \mathrm{MPa} \sqrt{\mathrm{m}}$ (Biomass) & \\
\hline & & $\mathrm{K}_{\mathrm{C}}=1.6 \mathrm{MPa} \sqrt{\mathrm{m}}$ (Biochar) & \\
\hline
\end{tabular}




$$
\begin{gathered}
\mathrm{a}_{\text {Biochar }}=0.7 \mathrm{~mm}(1 \text { cycles }) \\
\mathrm{a}_{\text {Biochar }}=0.9 \mathrm{~mm}(10 \text { cycles }) \\
\mathrm{a}_{\text {Biochar }}=2.3 \mathrm{~mm}(100 \text { cycles })
\end{gathered}
$$

Table 3: Inputs of the model equations for the specific heat capacity, the mechanical strength, the fracture toughness and the thermal reliability.

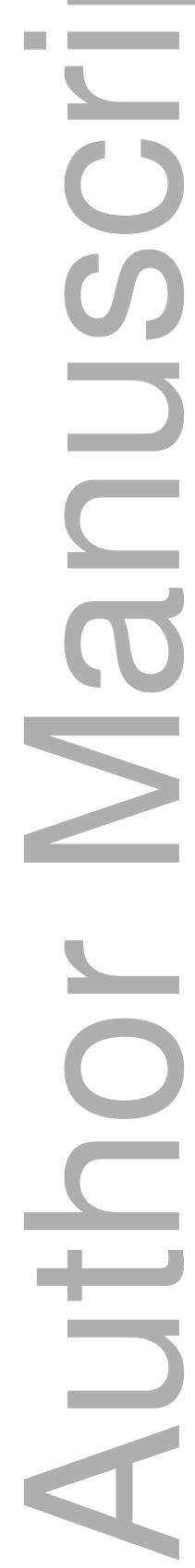




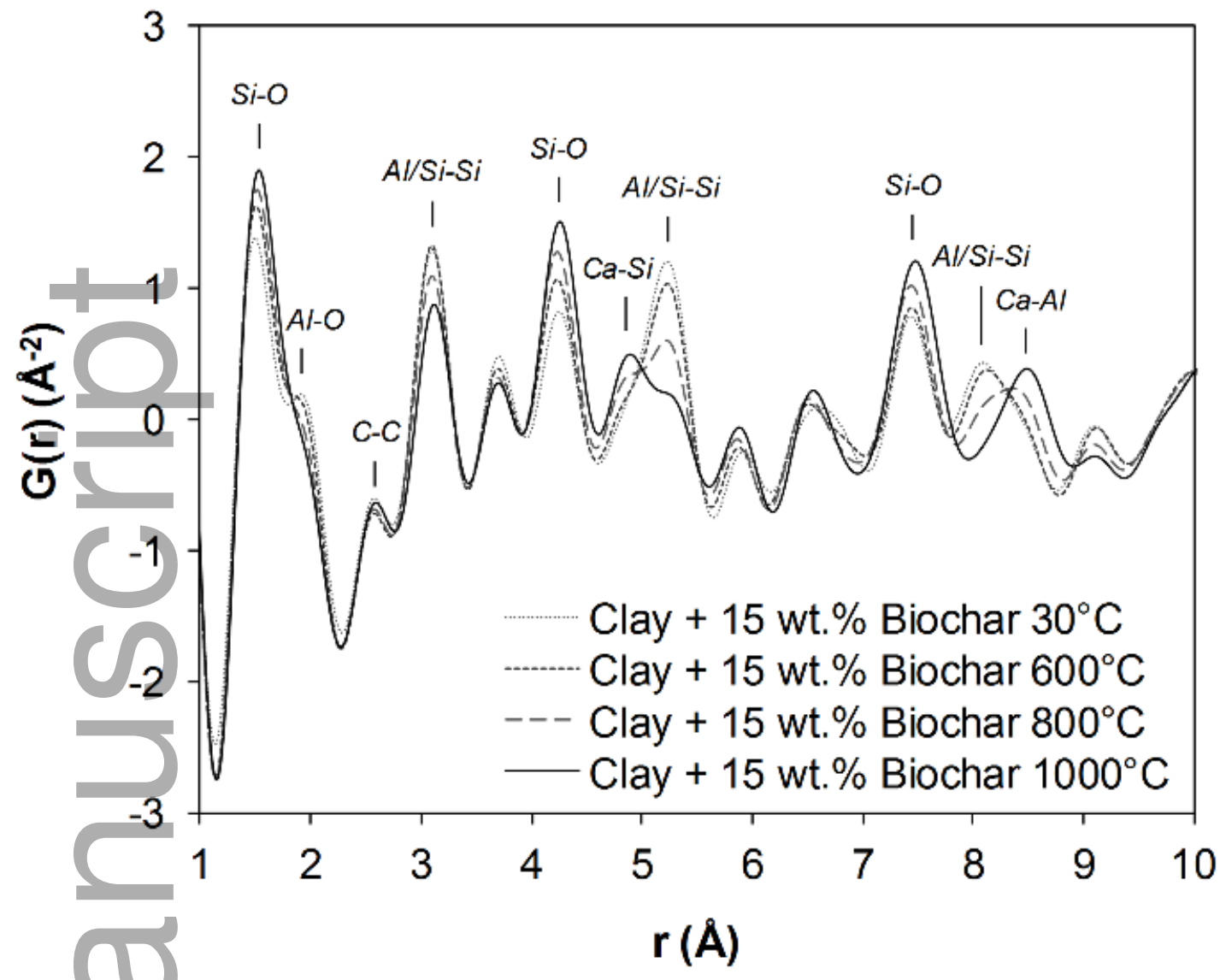

jace_15014_f1.tiff

This article is protected by copyright. All rights reserved 


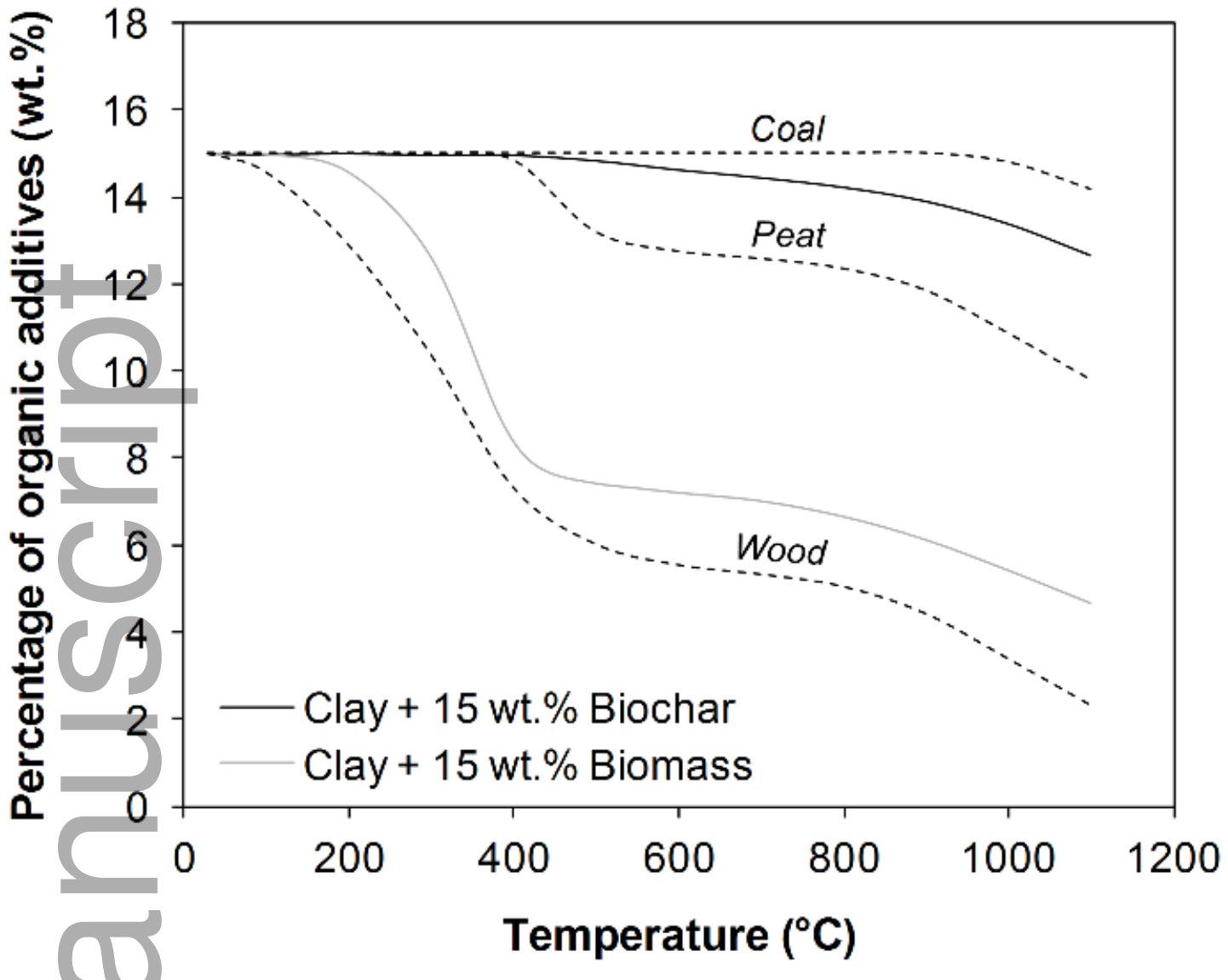

jace_15014_f2.tiff 

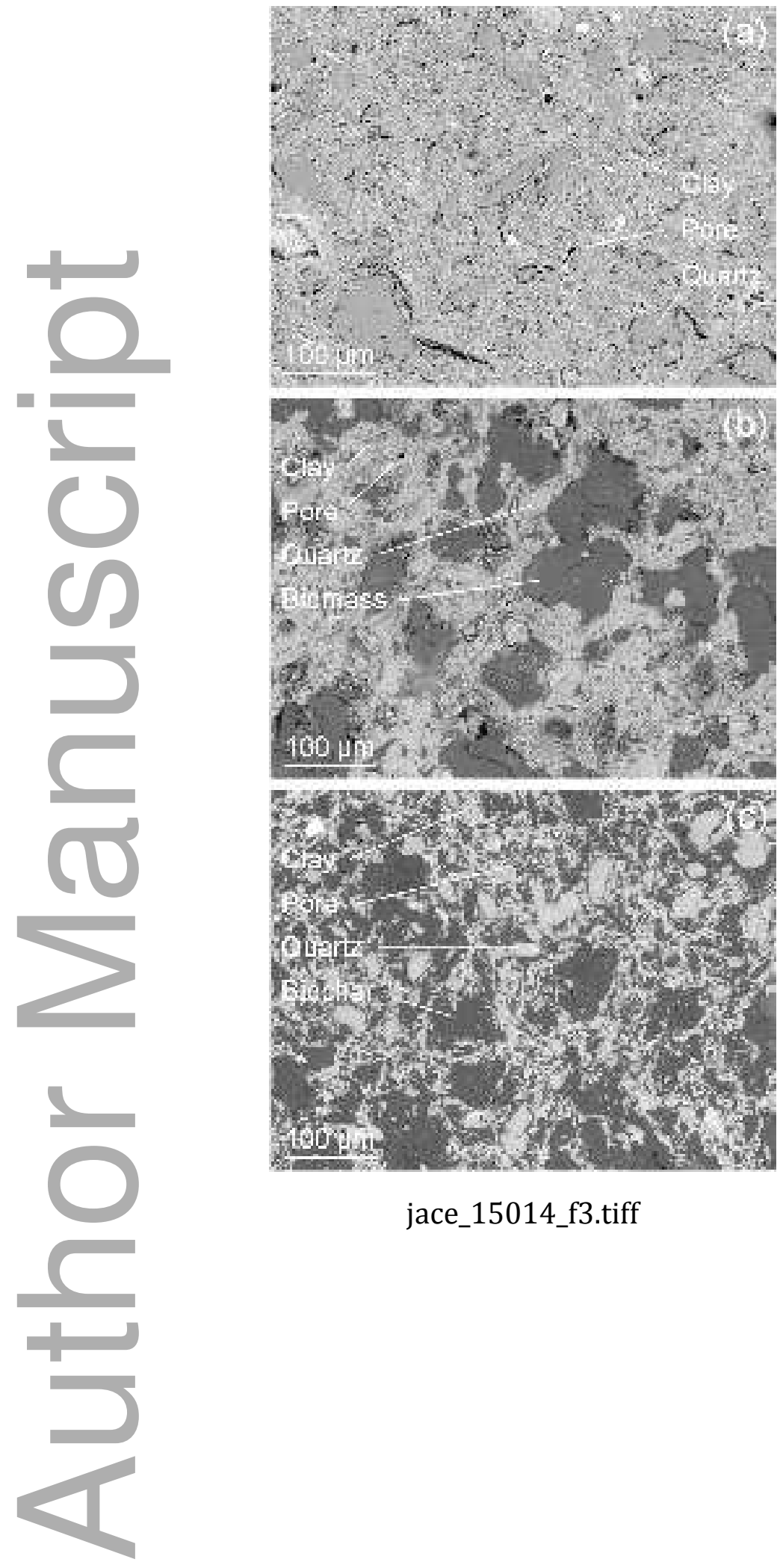

jace_15014_f3.tiff 


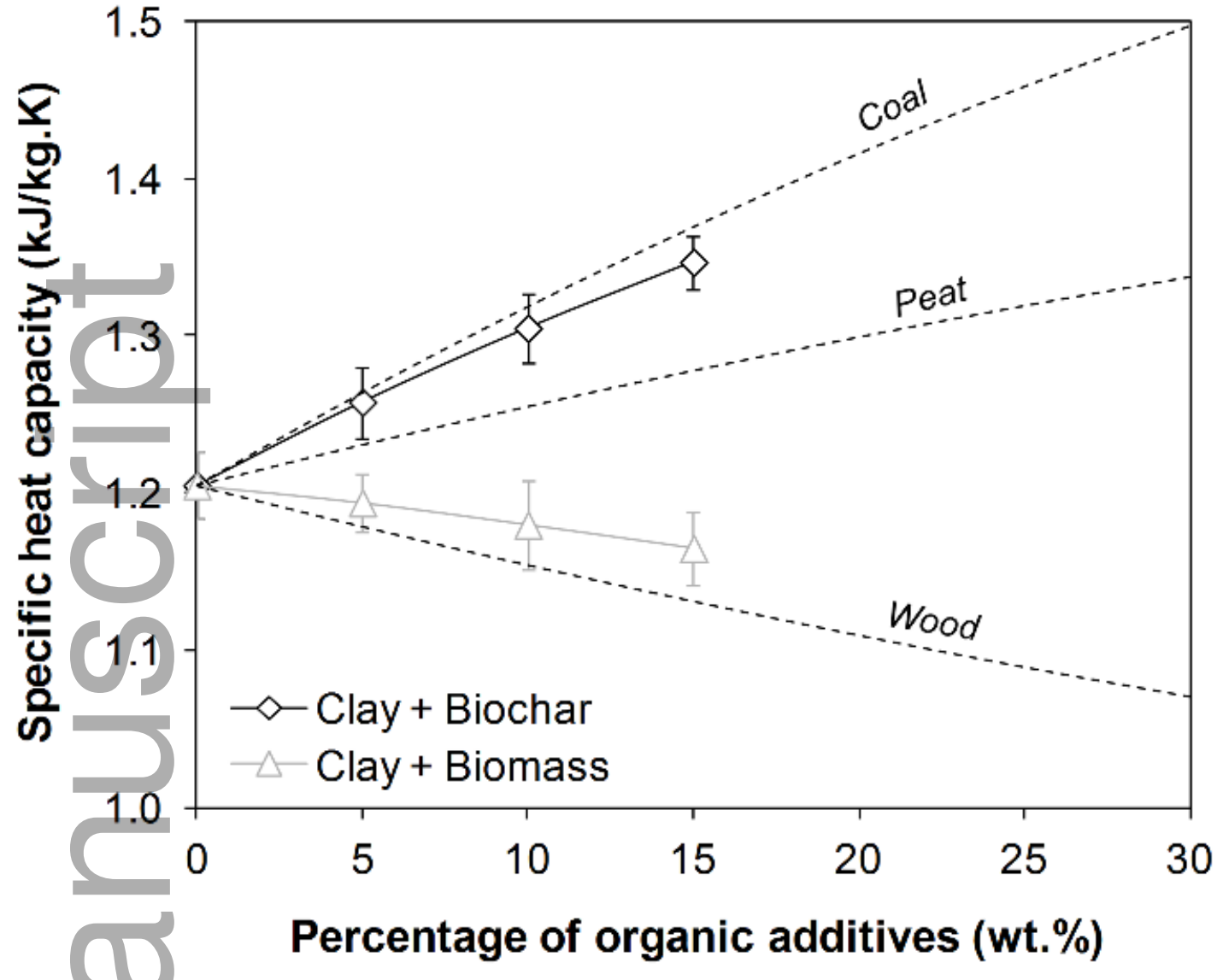

jace_15014_f4.tiff 


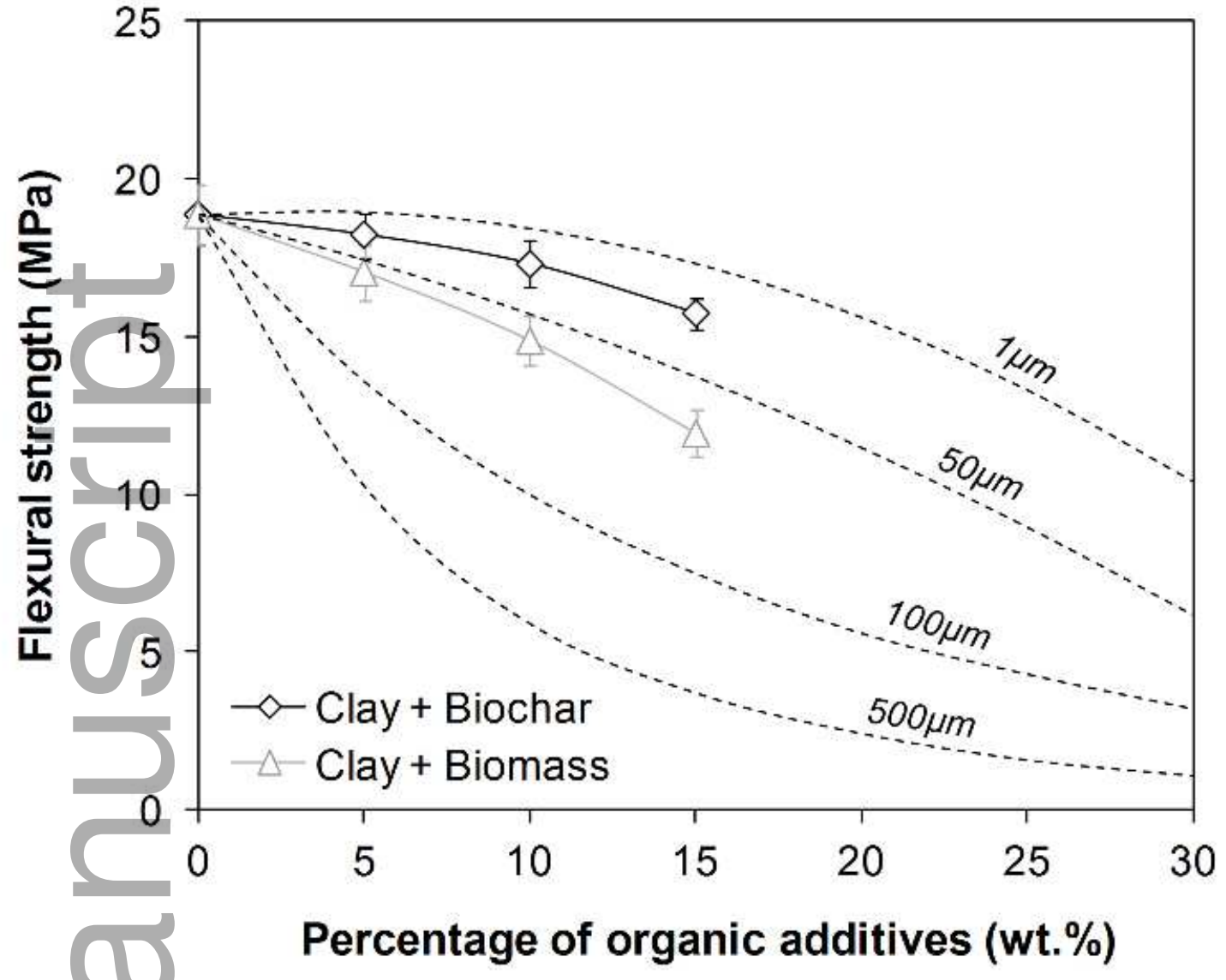

jace_15014_f5.tiff

This article is protected by copyright. All rights reserved 


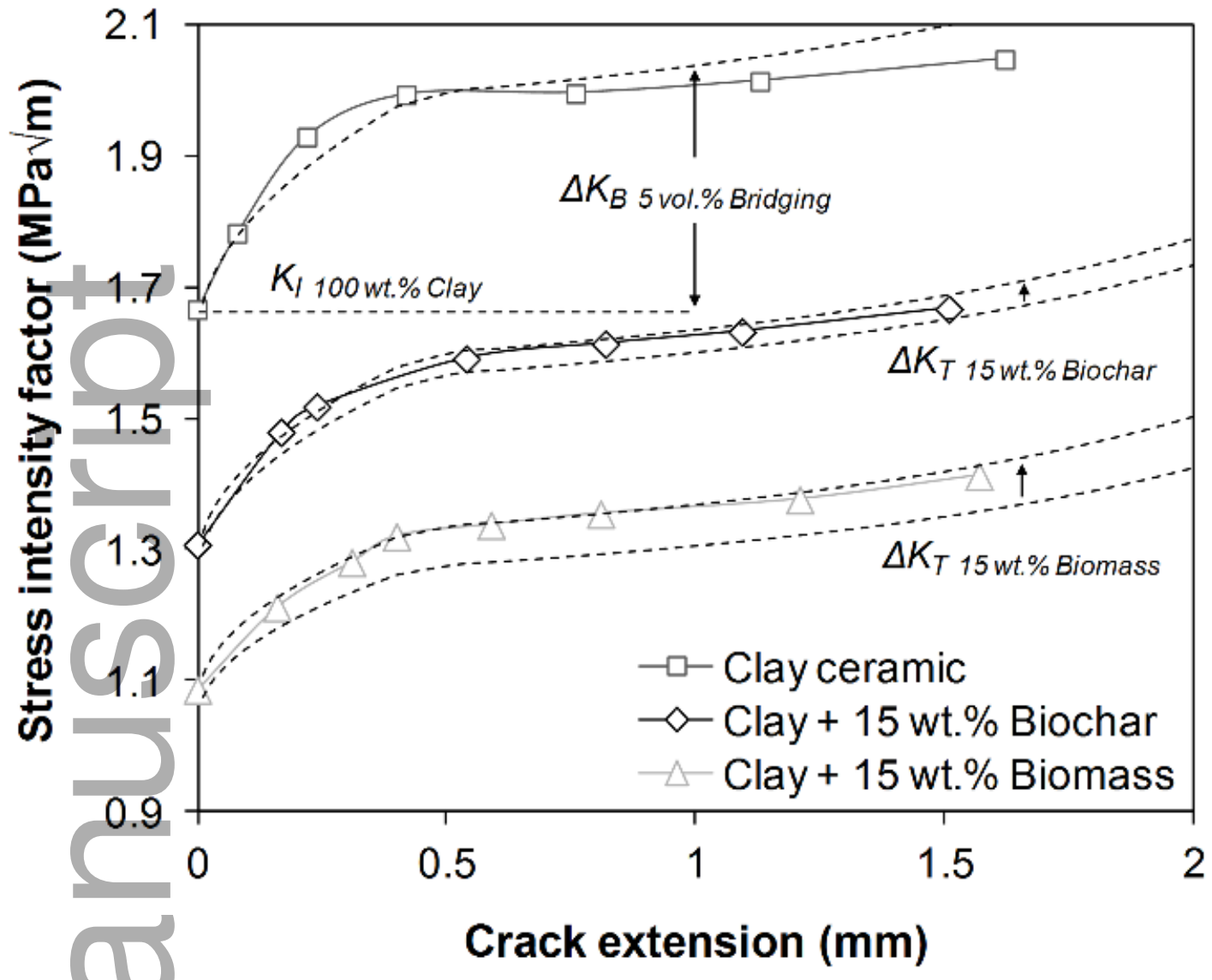

jace_15014_f6.tiff

This article is protected by copyright. All rights reserved 

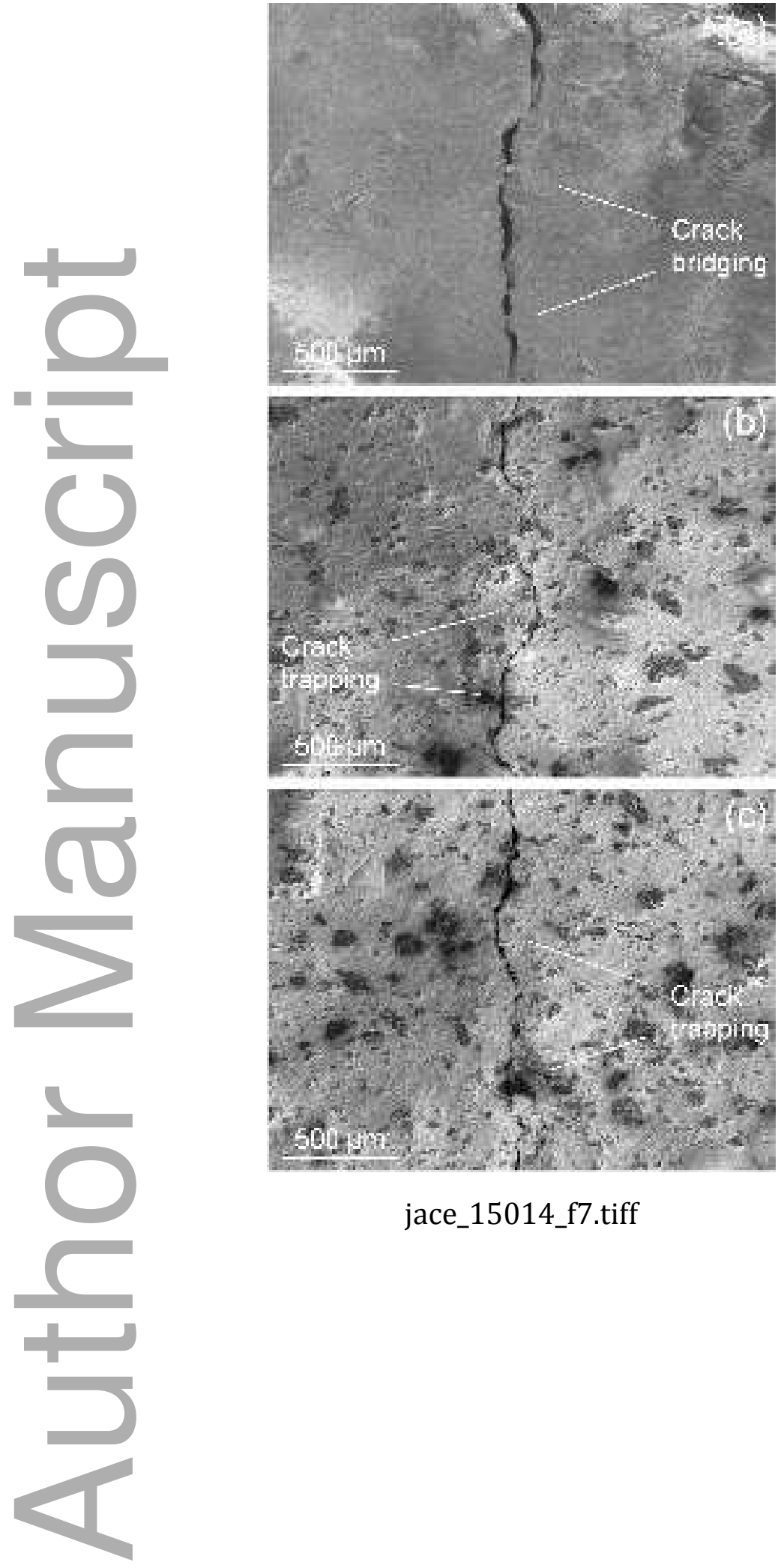

jace_15014_f7.tiff 


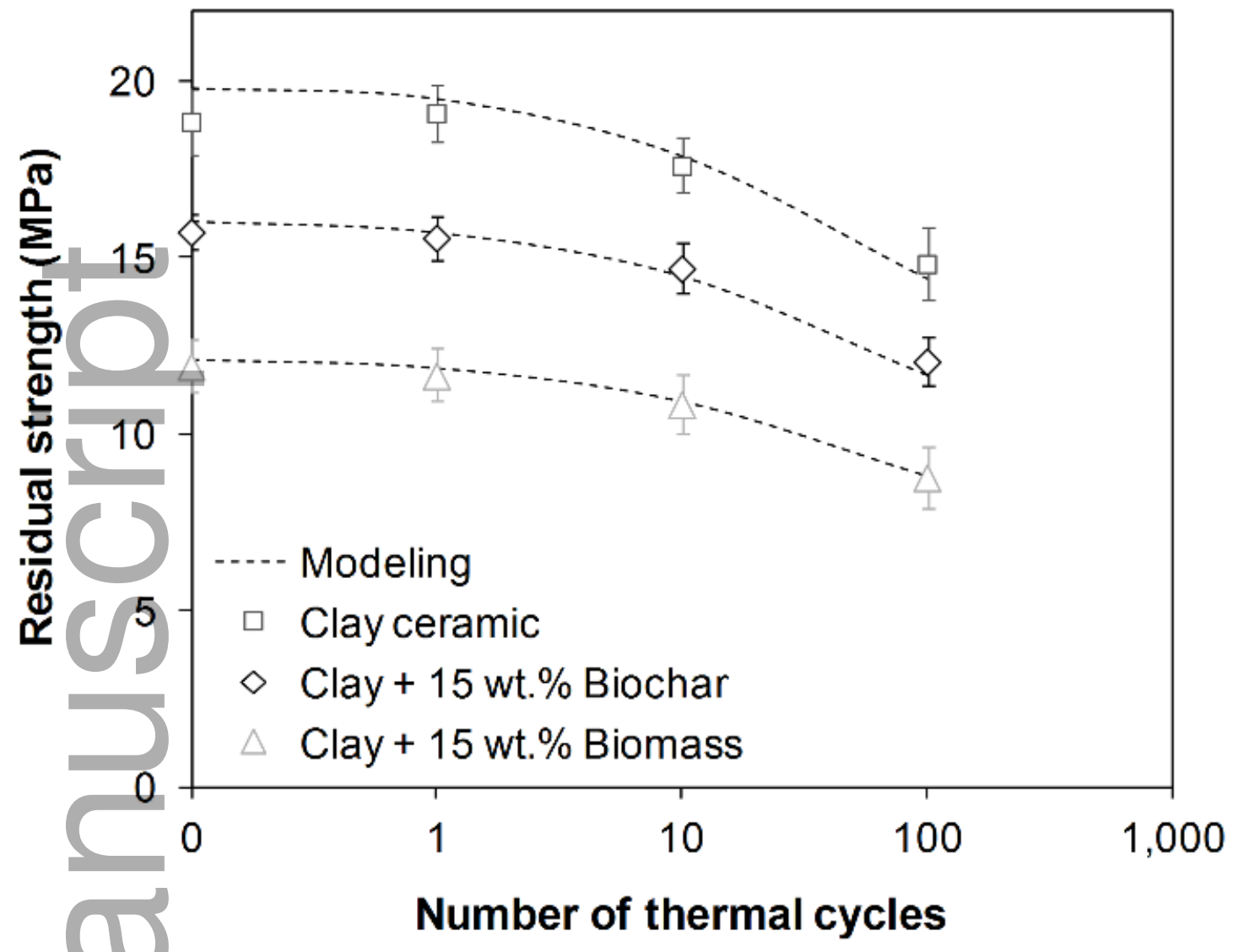

jace_15014_f8.tiff

This article is protected by copyright. All rights reserved 


\section{University Library}

\section{- M M N E R VA A gateway to Melbourne's research publications}

Minerva Access is the Institutional Repository of The University of Melbourne

Author/s:

Nigay, PM;Nzihou, A;White, CE;Soboyejo, WO

Title:

Structure and properties of clay ceramics for thermal energy storage

Date:

2017-10-01

Citation:

Nigay, P. M., Nzihou, A., White, C. E. \& Soboyejo, W. O. (2017). Structure and properties of clay ceramics for thermal energy storage. Journal of the American Ceramic Society, 100 (10), pp.4748-4759. https://doi.org/10.1111/jace.15014.

Persistent Link:

http://hdl.handle.net/11343/293050 